\title{
MAKING LANDSCAPES OF (BE)LONGING. TERRITORIALIZATION IN THE CONTEXT OF THE EU DEVELOPMENT PROGRAM LEADER IN NORTH RHINE-WESTPHALIA
}

\author{
Oliver Müller ${ }^{1}$
}

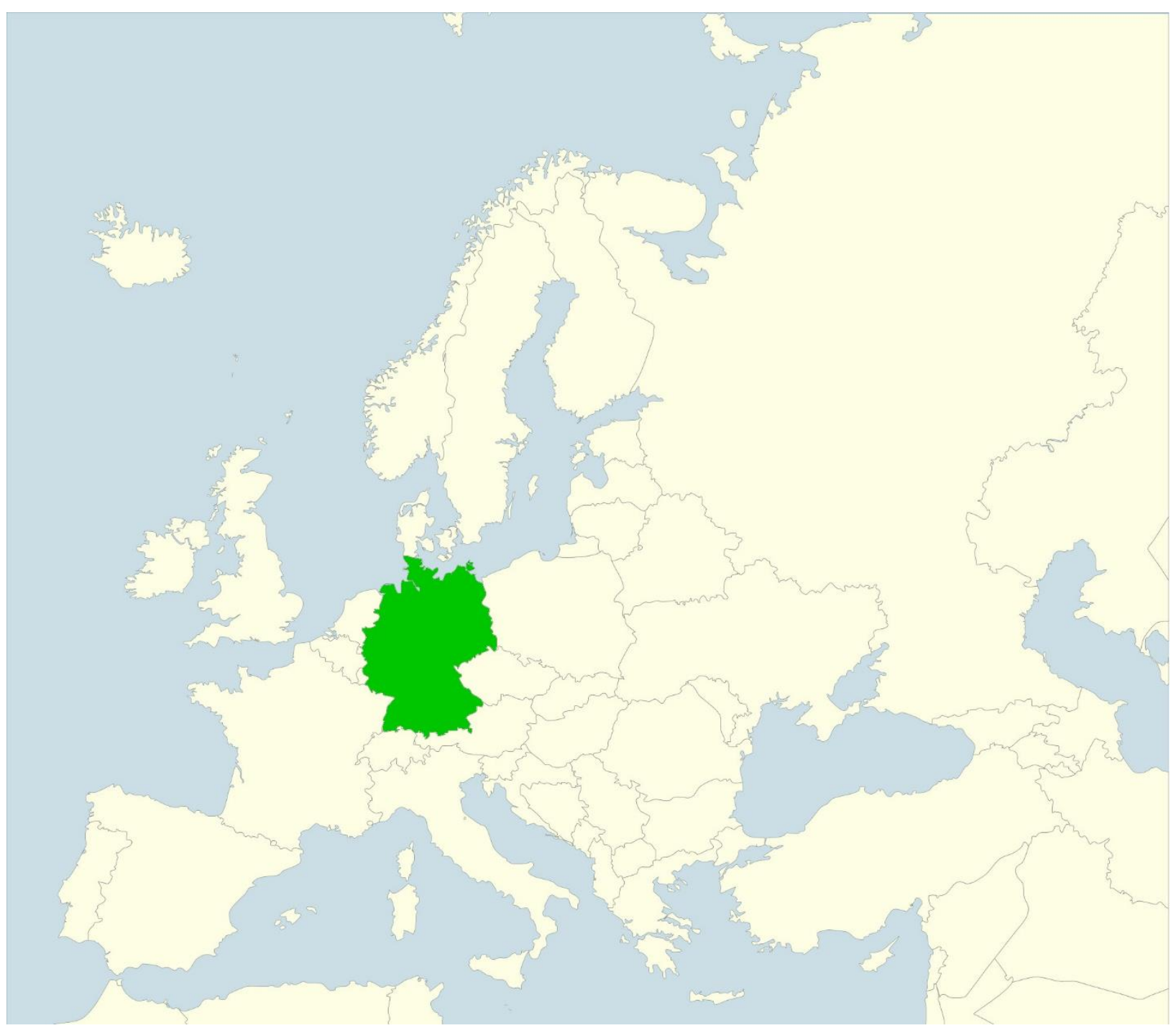

${ }^{1}$ Oliver Müller, M. A., Department of Cultural Anthropology and Folklore Studies, University of Bonn, Germany, ORCID: 0000-0003-0527-6308, e-mail: o.mueller@uni-bonn.de 
Abstract: The participation of residents in development processes is a keystone in current rural governance arrangements. The European Union's rural development program LEADER is an example of this, as it requests local residents to take action in the development process. Similarly, participatory forms of natural and cultural heritage preservation have increased significantly with the aim of revitalizing the socioecological fabric of territories. Following the Anthropology of Policy, the study employs an ethnographic approach to analyze the effects of bio-cultural heritage preservation strategies in the context of LEADER. Drawing on ethnographic data gathered during several field observations and semi-structured interviews in a LEADER region in North Rhine-Westphalia, the article investigates how a local LEADER initiative reconstructs a historical cultural landscape in order to valorize and exploit the biocultural heritage resources of their village. Residents articulate four interrelated senses of (be)longing while (re)making the biocultural heritage: 1) Political claim to use a resource; 2) place attachment; 3) politics of in/exclusion; and 4) nostalgic-utopian longing. As new knowledge actors in landscape governance, residents posit their perceptions, interpretations and valuations of the landscape vis-à-vis institutional actors of landscape governance and negotiate large-scale landscape transformations in the region investigated.

Keywords: Rural development - LEADER - Participatory landscape governance - bio-cultural heritage - territorial identity

Zusammenfassung: Die Beteiligung der Bevölkerung an Entwicklungsprozessen ist ein Eckpfeiler gegenwärtiger Governance-Arrangements im ländlichen Raum. Das EU Entwicklungsprogramm LEADER ist hierfür paradigmatisch, denn es fordert Bewohnerinnen und Bewohner dazu auf, sich am Entwicklungsprozess zu beteiligen. In ähnlicher Weise erfahren partizipative Formen der Erhaltung des natürlichen und kulturellen Erbes mit dem Ziel der Wiederbelebung des sozio-ökologischen Gefüges ländlicher Regionen eine beträchtliche Zunahme. In Anlehnung an die Anthropology of Policy verfolgt die Studie einen ethnographischen Ansatz, um die Auswirkungen von Strategien zur Erhaltung des biokulturellen Erbes im Rahmen von LEADER zu untersuchen. Auf der Grundlage ethnographischer Daten, die während mehrerer Feldforschungsaufenthalte und teilstrukturierter Interviews in einer LEADER-Region in Nordrhein-Westfalen gesammelt wurden, untersucht der Artikel, wie eine lokale LEADER-Initiative eine historische Kulturlandschaft rekonstruiert, um die Ressourcen des biokulturellen Erbes ihres Dorfes aufzuwerten und zu nutzen. Die Bewohnerinnen und Bewohner artikulieren vier miteinander verbundene Bedeutungen von Zugehörigkeit zur Landschaft während sie das biokulturelle Erbe rekonstruieren: 1) Politischer Anspruch auf Nutzung einer Ressource; 2) Ortsgebundenheit; 3) Politik der Ein-/Ausgrenzung; und 4) nostalgisch-utopische Sehnsucht. Als neue Wissensakteure in der Landschaftspflege positionieren die Bewohner_innen ihre Wahrnehmungen, Interpretationen und Bewertungen der Landschaft gegenüber institutionellen Akteuren der Landschaftspflege und verhandeln in der untersuchten Region weitreichende Landschaftstransformationen.

Schlüsselwörter: Ländliche Entwicklung - LEADER - Partizipative Landschaftspflege Biokulturelles Erbe - Territoriale Identität

\section{Highlights}

- LEADER induces local initiatives to exploit bio-cultural heritage as a development resource

- Local residents articulate four senses of (be)longing in participatory landscape reconstruction 
- Conflicts over perceptions, interpretations and valuations of historical cultural landscape

- Landscape governance is characterized by increased pluralization of knowledge actors

\section{Introduction}

This paper explores the dynamic links between the revitalization of biocultural heritage and placemaking strategies of local communities in the context of the European Union (EU) rural development program LEADER. It sheds light on the question of how rural residents create a sense of belonging in the process of material-semiotic landscape construction and how such processes are shaped by conflicts surrounding the authority to interpret and use the landscape. It departs from the hypothesis that LEADER projects provide a blueprint to negotiate large-scale macrostructural landscape transformations at the local scale when residents articulate a sense of belonging through practices of material-semiotic landscaping. In these processes, landscapes become a productive agent in the contested politics of rurality (Kamvasinou \& Stringer 2019, 784). On the one hand, cultural landscapes and their valorization has become a focus in rural development policies and there have been growing efforts to exploit the 'unique' character of cultural landscapes and the linked biocultural heritage as a resource for rural development (Cejudo et al. 2020). On the other hand, policymakers and scholars alike reckon the challenges posed to the viability of rural economies "local, regional and national scales, human cultural values and attachments, biocultural resources and assets, and associated biodiversity are progressively degraded" (Rotherham 2015, 3410). Consequently, rural areas are targeted with 'bottom-up' development instruments, such as the EU's LEADER program, which seeks to involve local communities in so-called 'LEADER projects' in order to exploit the culturally situated knowledge, place-based identities, meanings, values and skills of communities in relation to their everyday environments. Therefore, LEADER projects call upon local residents to actively contribute to the design, reconstruction and use of cultural landscapes as a local resource by providing financial support for the implementation of landscaping measures.

However, the participation of local residents in practices of landscaping entails conflicts between public authorities and residents regarding rights of use, the interpretation of landscape, its composition and ownership. Such conflicts arise between local communities' priorities, needs and goals regarding the management of landscape and other institutional levels, and are linked to diverging knowledge regimes when locally situated knowledge come into conflict over interpretation power with the scientific-bureaucratic expert knowledge regimes of landscape governance (Lowe et al. 2019). This article analyzes and brings together these different dimensions of the political negotiation of cultural landscapes at the local level and proposes the term "landscapes of (be)longing." It is employed to investigate the entanglements of institutional landscape governance, local placemaking practices and the intimate relationships between local residents and their environments. (Be)longing captures the relationships between a local community and its natural environment in a fourfold sense: 1) The political claim to use a common resource, which engenders a sense of a body politic; 2) as an emotional attachment to a place; 3) as a political arena of in-/exclusion; and 4) as a nostalgic/utopian longing for ideal human-nature relationships. By differentiating between these dimensions, the concept is useful to understand the conflicts arising in participative landscape management. In doing so, the paper contributes to the growing debate on managing landscape changes and environmental transformation in rural areas (Bieling et al. 2011), culture-based conservation strategies (Gavin et al. 2014) and the growing debate on multi-stakeholder participation in landscape management (Jansson et al. 2019; Kusters et al. 2017). Eventually, the paper claims that policies addressing the valorization and conservation of biocultural heritage have to engage with the everyday and vital "vernacular expertise" that development agents have of the place in which they live in order to understand the negotiation processes and resolve conflicts of landscape governance (Lowe et al. 2019, 31).

Firstly, I will expound the history of the EU territorial development program LEADER and relate it to the recent turn to biocultural heritage as a resource for rural development. In a second step, 
the LEADER project "The Poplar Pasture" is introduced and the four dimensions of landscapes of (be)longing will be exemplified. The paper concludes by pointing out the need for research on cultural landscape and biocultural heritage revitalization strategies to engage with understandings of landscape, which are linked to everyday practices of doing landscape as a lived environment.

\section{LEADER and Territorial Development}

Starting in 1991, the aim of LEADER has been to diversify rural economies by activating rural areas' 'endogenous' sociocultural and ecological resources, promote non-agricultural activities and stimulate rural development towards a multifunctional and territorial approach (Almstedt et al. 2014, 301). LEADER has a distinct 'bottom-up' methodology, which seeks to foster 'endogenous development' by making use of local resources, building on the development needs of local people, who should actively participate in the design and implementation of development projects (Müller et al. 2020). In accordance with the New Rural Paradigm (Organisation for Economic Cooperation and Development), the LEADER approach aims to exploit the potential of rural development assets, while concomitantly enhancing the self-governing capacities of local communities. LEADER projects focus predominantly on social infrastructures, the provisioning of basic services and capacity-building steered toward the enhancement of local communities' sociocultural capital. However, there are increasing efforts to integrate the recovery and enhancement of biocultural heritage into rural development goals in the current funding period 2014-2020 (Marango et al. 2020, 5). There seems to be a "commitment to the vernacular, to local and rural identity, along with the promotion of natural and cultural values [...] to revitalize and sustain the productive fabric [...] while making use of endogenous resources" (Cejudo et al. 2020, 253), in an attempt to counter the continuing degradation of natural resources and promote sustainable rural development.

At a EU level, the diversity of biocultural heritage of rural areas is framed as a "unique part of our common identity," contributing to the quality of life in rural areas, promoting a "sense of belonging" and considered to be a "driving force for social and economic development" (Kulmer 2012, 92). Biocultural heritage is, therefore, conceptualized as a resource that has the potential to provide economic alternatives in ecological strategies pursuing the multifunctionality of rural territories, which are more sensitive to and respectful of historically evolved and place-based ecological values (Cejudo et al. 2020, 253). However, EU rural policies partly contradict the re-emplacement of socio-ecological relationships and provoke conflicts of objectives. The EU Habitats Directive, for example, contributes to the levelling of cultural landscapes across Europe because of general landscape classifications to the detriment of regional characteristics and identities (Printsmann et al. 2012).

In contrast to 'pristine' nature, cultural landscapes are valued as a resource for sustainable territorial development. Firstly, they are valued as amenity landscapes for recreation and tourism (Abrams et al. 2012; Rotherham 2015). Secondly, as a manifestation of socio-ecological relationships in place, they lie at the heart of territorial identities, which LEADER seeks to promote, thereby re-embedding social relationships in place (Ray 2001). The European Landscape Convention, as one prominent policy example, urges states to recognize cultural landscapes "as an essential component of people's surroundings, an expression of the diversity of their shared cultural and natural heritage, and a foundation of their identity" and to engage with local communities as partners in the planning and management of landscapes (CoE 2000, Art. 5). The term biocultural heritage has gained currency to capture this dynamic interplay between natural resources, cultural practices and place and to provide a "holistic approach crosscutting conventional boundaries between biological and heritage conservation, rural development and local participation" (Lindholm \& Ekblom 2019, 2). This holistic understanding of biocultural heritage comprises local environmental knowledge, lived practices, memories, meanings and values of rural residents, and material landscape features and biological resources (including genetic variation and species diversity) of the humanly managed environment (lbid.). Given the preceding arguments on the increasing role of biocultural heritage as a driver for rural development, the following section explores the links between biocultural heritage and rural development in the light of participatory culture-based conservation. 


\subsection{Biocultural heritage and rural development}

Cultural landscapes offer an integrated view of the relationships between biological and cultural diversity at the landscape level. The concept points to the interdependencies between tangible physical patterns, the social structures of ecosystems and intangible cultural heritage (Taylor et al. 2014, 2). "Cultural severance" describes the loss of cultural memory, knowledge, skills and values linked to traditional customary land management, leading to a long-term loss of biodiversity and landscape qualities (Gelencsér et al. 2012; Rotherham 2015, 3405). In order to counter the degradation of biocultural heritage assets, cultural landscapes become the object of revitalization strategies, which seek to integrate the conservation of nature and cultural heritage. Biocultural heritage (such as traditional land management) is recognized as central for the preservation of biological diversity in development strategies (Bridgewater \& Rotherham 2019). The biological and socio-material features of the landscape intertwine, its habitats and species become manifestations of long-term biological and cultural relationships, encompassing tangible and intangible cultural expressions such as memory, experience and knowledge (Lindholm \& Ekblom 2019, 2). Biocultural heritage consists of - indirectly or intentionally biological manifestations of cultural practices and the knowledge which guides these practices developed within a specific social-ecological context. Examples are common property systems, customary use rights, traditional land use practices and management systems. Local environmental knowledge of biological cultural traces is embedded in worldviews, value systems and everyday experiences of the local environment.

Rural development policies, such as LEADER, seek to valorize and exploit such "heritage assets" through the revitalization of place identities, cultural memories and historical landscaping practices, reflecting the idea that "the meaning and value people assign to material manifestations of culture relates to the extent people actually live on and work with the landscape" (Eriksson $2018,6)$. Vice versa, preserving the cultural memory of these land management systems in cultural expressions is central for the recognition of biocultural heritage resources: "[C]ultural memory promotes perceptions of heritage values, but also that such a cultural memory partly depends on the current utility of these landscape elements" (Eriksson 2018, 13).

Despite the support for place-based, community-led landscape conservation in rural policies and the recognition that conflicts over landscape change are growing in number and scope (Kühne $2019,5)$, there is little research on how policy-driven biocultural heritage preservation plays out in practice, and how conflicts related to divergent interpretations and valuations of cultural landscapes are negotiated (Kidd 2018, 548). On a general level, it is noted that the endogenous focus on the local control of territories and resources in rural development theory sits uneasily with environmental policies and multiscalar governance operating at (regional) landscape level and beyond (Marango et al. 2020, 5). There is a widespread recognition that local communities and their cultural-ecological knowledge practices must be integrated into formal planning procedures in order to move beyond "fortress conservation" and towards community-based conservation to bring about sustainable conservation of biocultural heritage (Clarke 2015; Heatherington 2012, 165; Kühne 2019, 117). Raising concerns about community participation, Selman points out the diverging regimes of valuation that exist between "insiders," such as local residents, and "outsiders," i.e. public authorities and sectoral agencies, but also tourists or recreationists (Selman 2006, 213). Stemmer et al. emphasize that conflicts in participatory landscape management result from incommensurability between experts' 'objectivist' criteria of landscape assessment and the emotional-esthetic value judgments of the lay public. Even though differences between cognitive models of the respective disciplines' specialized knowledge and everyday perceptions and valuations have been largely described in theory, empirical studies are rare (Stemmer et al. 2019, 510).

Taking into account the tensions between these divergent regimes of perceiving, valuing and knowing biocultural heritage, the following section outlines the methodological strategy to research conflicts linked to participatory landscape management. Such conflicts arise when local residents are called upon in participatory strategies to contribute to the development of their region by making use of what they consider to be their environmental assets and resources. 


\section{Methodology}

The methodology has been designed in order to navigate between the poles of 'bottom-up' landscape practices by voluntary and community-led initiatives and 'top-down' perspectives on landscape development manifest in institutional frameworks of landscape planning and nature conservation. The research agenda focused specifically on the material, imaginative and symbolic practices of perceiving, knowing and doing landscape, thereby, following a threefold analytical framework for exploring (rural) space (Halfacree 2006). The case study was conducted between 2018 and 2019 as part of the GRF (German Research Foundation) project "Participative development of rural regions. Everyday cultural negotiations of the European Union's LEADER program," conducted between 2017 and 2021 at the Department of Cultural Anthropology and Folklore Studies, University of Bonn. There exists an extensive body of research on LEADER as method for local rural development. Studies have focused on a wide range of topics, such as institutional capacity building of Local Action Groups (LAGs), investigations of rural partnership workings and the influence of local elites or comparative analyses of the different experiences of implementation in heterogeneous national policy contexts (Konečný et al. 2020; Furmankiewicz et al. 2010; Pollermann et al. 2020). However, despite the fact that most of the LEADER activity takes place at the project implementation level, few studies investigated the effects of LEADER on the everyday life of villagers (Pollermann et al. 2014). The aforementioned research project aims to consolidate the understanding of how the community-led local development approach of LEADER impacts everyday life of local residents' worlds. It investigates which actors participate in which way in the local implementation of LEADER, how the development measures affect the everyday worlds of local residents and how they actively translate the measures into their everyday lives.

The methodology of the case study draws on the ethnographic approach of the Anthropology of Policy to investigate the everyday life effects of LEADER. The author followed the LEADER policy into the different local arenas of implementation in order to observe how it was linked to different actors, discourses, practices and material artefacts. This article draws on both ethnographic and interview material. The ethnographic data was collected during six field observations of official events related to the LEADER project "The Poplar Pasture." Occasions for the field observations were project presentations, history days and visits from the federal state parliament (Landtag) and federal parliament (Bundestag), during which the initiative produced rich representations and performative enactments of the poplar pasture landscape. To gain access to these formats, I contacted the chairperson of the local LEADER initiative through the regional manager of the LEADER region and openly communicated my research interest in the local effects of LEADER. Furthermore, participant observations were recorded during a two-week residency in the nearby municipal town in September 2018. During this time, I made numerous field visits to the village neighboring the poplar pasture where most of the members of the LEADER initiative live. Walking the poplar landscape in company with residents, I conducted informal interviews to understand the everyday perceptions and practices of doing the landscape as part of a lived environment. During these field observations, I became acquainted with the members of the local LEADER initiative, residents of the village as well as other stakeholders involved in project implementation. The sampling strategy set out from the hypothesis that local residents' perspectives, perceptions and practices related to the poplar pasture landscape would differ substantially from institutional landscape governance actors. The collection of interview data was based on an inductive sampling for which I used my knowledge of the local context acquired during the fieldwork period and interviewees were recruited on the basis of their involvement in project implementation. The interviews were taped, transcribed and analyzed using the qualitative methodology software MAXQDA.

The interview data encompasses two sets of interviews and totals eleven semi-structured interviews ranging between one and two hours. The first set of six interviews were conducted with members of the citizen initiative, local residents and the voluntary landscape warden. These interviews aimed to understand the everyday perceptions and valuations of the poplar pasture landscape from the perspective of the inhabitants. One of the interviews with the initiative was conducted as a focus group discussion. This approach was employed in order to explore the "collective orientation frames," which are constituted by shared (biographic) experiences and 
is articulated in metaphorically dense "orientation figures" (Bohnsack et al. 2018, 76). During the interview, respondents detailed their biographic affiliations and everyday practices related to the poplar pasture, as well as their moral-esthetic considerations for its recultivation. The interviews were complemented by field notes and informal interviews conducted during walks and other group activities taking place on the pastures. These participant observations helped me to understand the practical enactments of specific symbolic representations and imaginations of the landscape.

The second set of five interviews was conducted with planning practitioners and key stakeholders in the management of the areas that encompass the former poplar pasture, i.e. the lower nature conservation agency, the forest authority, the water authority, the district farming association and the local authority estate office. These interviews focused on ways of knowing the landscape from the perspective of institutional landscape governance and practical conservation management. The interview partners were contacted because of their involvement in an early stage of the project development when the regional management invited them to a roundtable discussion together with the LEADER initiative. Furthermore, the interviews focused on investigating how local authorities interpret local residents' understandings of the landscape and how they negotiate their demands of recultivating the poplar pasture. The interviews are complemented by a document analysis of authoritative and binding frameworks for the work of landscape governance and practitioners, such as the district landscape plan and the EU Habitats Directive objectives for the area protected. The following section contextualizes the LEADER project "The Poplar Pasture" briefly by outlining the landscape-related development goals of the Local Development Strategy (LDS) of the LEADER region "Thousand Plains." This policy framework propounds an agroecological vision for the future development of the landscape and forms the context for the recognition of the LEADER initiative "The Poplar Pasture" as a legitimate actor in landscape management.

\section{LEADER project "The Poplar Pasture"}

The LEADER region "Thousand Plains" is located in a peri-urban area in-between three major agglomerations in the German state of North Rhine-Westphalia. Due to the highly productive agricultural land and opencast mines in the region, it is structurally similar to what Michael Woods (2007, 486) has termed the "global countryside": The successive incorporation into global agricultural and energy markets in the course of the last 70 years has significantly reshaped the sociocultural, economic and material landscape of the region. Specifically, the socioeconomic and technological transformation into a productivist countryside induced by agricultural intensification and modernization in the region investigated, have led to the transition from a smallholder agriculture to an industrial, globalized agricultural economy and the successive abandonment of traditional land management systems and farming practices (Heidner 2018).

The social-ecological transformation of the landscape is problematized in the LDS of the LEADER region "Thousand Plains." The SWOT analysis attributes a lack of "regional identity" and "regional self-awareness" to the landscape transformations described above. Due to the absence of a "historical landscape image," the LDS attests a lack of distinctiveness and describes the landscape as a "no-man's-land in-between the cities A, B and C." Concomitantly, legacies of natural and cultural heritage are considered as "assets" to be preserved and enhanced in the development process. Remaining historical cultural landscape traces are valued as key in preserving habitats for rare and endangered species, thereby, contributing to the conservation of biodiversity (LDS 2014: 46). As a development goal, the LDS, thus, aims to: "Protect, maintain and valorize the remaining and/or renaturalized cultural landscapes such as orchard meadows, community forests, river floodplains. They are important roots for the regional identity and offer links to traditional and sustainable forms of management according to the principle protection through use"' (LDS 2014, 41).

The LEADER project "The Poplar Pasture" was incorporated into the LDS in the participatory design process as a lighthouse project in 2014, but it took around a year from the official launch of the LEADER process in 2015 until the project beneficiary, a local citizen association, was founded in 2016 under the auspices of a local cultural heritage association. The preservation 
efforts have been pursued by a precursor association of local residents, loosely connected as an interest group, since 2014. The LEADER initiative pursues several objectives: 1) Recultivation of the wooded pastures as a semi-open floodplain landscape; 2) grazing with native livestock breeds; 3 ) suppressing the spread of "invasive neophytes" by the cattle; 4) preservation of "native" species specific to the habitat; and 5) increasing the identification of the inhabitants with the landscape and enhancing its use as a recreational area.

\section{1 "The Poplar Pasture" landscape}

This landscape is called a Driesch in the local idiom: Driesch, Dreesch or Triesch generally refers to exhausted or unproductive arable land which was first used as fallow land and then as pasture for livestock grazing. This particular Driesch is a floodplain landscape that stretches along the meandering sections of a river in North Rhine-Westphalia and encompasses roughly 50 hectares, while the extension fluctuates with recurrent inundations. The local farmers managed this Driesch as a community member property in the ownership form of the commons until the municipal territorial reform in 1972. After the reform, a tenure system was introduced and the land was demised as public property to the larger municipality as legal successor of the dissolved citizens' municipality (Ortsbürgergemeinde). As of then, cattle farmers had to pay a tenure to the municipal administration for livestock grazing on the pastures (private communication, local authority estate office), which induced a spatial reordering. The territorial self-management, i.e. pastoral commoning, was replaced by enclosures of land which had formerly been collectively used to be concentrated in larger units as the prerequisite for agricultural rationalization. This development took place throughout Europe and is often referred to as the "enclosure of the landscape commons" (Olwig 2013, 31). As a result, the size of individual pastures increased by merging smaller areas into larger agricultural estates. The areas previously operated by several farmers were then managed by only one farmer.

Farmers used the Driesch as wooded pasture for livestock grazing and forestry until the 1970s. Up to that time, the common pastures were planted with hybrid poplars, a crossbreed between the native black poplar and the Canadian poplar (HFR 1986, 41f.) Each household was entitled to plant and use up to 130 poplar trees on the pastures and mark them with the number of their house (Hausnummerpappeln). This right was coupled to the requirement of tree owners regarding silvicultural land use (HFR 1986, 41f.). The hybrid poplars were popular due to their even growth and rapid rotation period of 30-40 years. The softwood was used as firewood, for the production of wooden shoes (so-called clogs), matchsticks and allegedly shipped to Asia for chopstick manufacture. In customary use, poplar trees were given as a dowry for the wedding couple, who were then required to replant poplars for their offspring and keep the generational cycle alive. The dual use of poplar pastures gave the Driesch pastures a characteristic appearance as a semiopen pastoral landscape, which has resulted in the designation of toponyms and family names still vivid in the cultural memory of the region. The devaluation of poplar wood, due to the availability of cheap softwood following the globalization of markets in the 1970 s to 80 s, coupled with a paradigm shift to "close-to-nature forest management," banning the replanting of nonnative tree species in 1990, instigated the gradual decline of poplar agroforestry in the region (LWL \& LVR 2007, 85).

The structural change from a smallholder agriculture to an industrial, globalized agricultural economy, linked to the changed land management regime, instigated the successive abandonment of the Driesch pastures. After the dissolution of woodland grazing rights (Schweidrecht) in the 1980s, a customary law which regulated the private and commercial use of poplar wood, the legal separation of forests from agricultural land took place. Today, grazing in the area designated as forest is only permitted in contractual conservation agreements, the socalled cultural landscape program (Kulturlandschaftsprogramm) of the federal state (Heidner 2018, 31). Roughly, 80 per cent of the poplar tree population fell in 2014 during a series of consecutive Pentecost storms. The remaining poplar trees are private property but are subject to a tax levelled by the municipal administration. The private replanting of poplar trees is forbidden as the forest is managed by the district forest authority and subject to management plans. Meanwhile, a large part of the former Driesch area is overgrown with "invasive alien species," above all, glandular balsam and giant hogweed, so that the appearance of the Driesch has 
changed almost to the point of topographical levelling. The floodplain areas encompassing the former pastures have been protected as a Special Area of Conservation under the EU Habitats Directive since 2013. The management plan aims to renature ("natural development") the areas into a "priority habitat of community significance," i.e. riparian alluvial forest, thereby, precluding any cultivation (LANUV 2013,5 ). These administrative, socioeconomic and cultural shifts in land management have generally led to the gradual demise of traditional Driesch management.

To the degree that the former "taskscapes" (Ingold 2001, 201) of local residents have changed (from subsistence farming to leisure and recreation), the spatial image of the Driesch as a valuable 'intact cultural landscape' has become the focus of attention of a local citizens' initiative. A local citizen initiative was founded in 2014 to counter the effects of cultural severance. In 2018, it received LEADER funding for a feasibility study to explore the possibilities of grazing the former Driesch area. The feasibility study, while adhering to 'objective' scientific methods when evaluating ex ante the material effects of grazing on soil, water, habitats and species diversity, eventually makes a plead for recultivation from the cultural vantage point of value-based landscape interpretation. The Driesch landscape is 'intact' only insofar as it possesses idiosyncratic individuality. The disappearance of the cultural landscapes' unique character and the introduction of "regionally untypical landscape elements," the feasibility study argues, ensues a loss of "feeling of home" [Heimatgefüh/] and decline of regional identity among residents (Heidner 2018, 45). This structure of argumentation builds on the justification of conservation based on the German idea of local cultural heritage conservation [Heimatschutz], which developed at the turn of the $20^{\text {th }}$ century as an anti-urban and civilization-critical movement. According to this conservative view, nature conservation should contribute to homeland preservation. Landscapes in this cultural landscape ideal are regionally specific units of 'nature' and 'culture' in their idiosyncratic (and inextricable) interweaving of landscape and people [Land und Leute]. This individual and organic harmony of 'culture' and 'nature' is expressed in a characteristic landscape image, the objective of conservation being to preserve the specific 'character' against utilitarian rationality, uniformity and egalitarianism (Kühne 2019, 12). This moral-esthetic approach to landscape is still widely prevalent in German voluntary nature conservation and subject to recurrent critique ${ }^{2}$. While it is not the objective of this article to review the arguments in favor of or against this landscape paradigm, the following sections explore how the LEADER initiative adopts this cultural landscape ideal to unleash a cultural logic of (be)longing to and in the landscape into the supposedly neutral domain of landscape governance. As a precursor, the notions of landscape and belonging are briefly elaborated.

\section{Exploring the links between landscape and (be)longing}

The concept of belonging has received widespread attention in social theory, feminist and decolonial scholarship in particular (Yuval Davis 2011). It is used to grasp the multidimensional, dynamic and performative ways of creating attachment to something. According to Probyn (1996, 19 ), belonging has to be thought of as a dynamic and processual "longing," rather than a fixed identity. She considers it to be "some sort of attachment, be it to other people, places, or modes of being, and the ways in which individuals are caught within wanting to belong, wanting to become, a process that is fueled by yearning rather than the positing of identity as a stable state." Belonging is an ambiguous term that carries individual and social dimensions, which interlink as "personal, intimate, and affective dimensions of belonging converge with, help generate, and are generated by more structured, public and political aspects" (Wright 2020, 295). It is simultaneously personal, an emotive capacity of affiliation and sociopolitical and mediated by power relationships (Ahmed 2004). Feminist and decolonial theory have recently extended the focus from ideas of belonging as sameness to "belonging-as-difference" to encompass an openness to difference, more-than-human entanglements and inclusive politics of belonging (Wright 2020, 293).

\footnotetext{
2 Bruns et al. (2015, 45-46) have conducted a critical review of the German local cultural heritage conservation [Heimatschutz], its cultural landscape ideal and its links to anti-democratic ideas and National Socialist 'blood and soil' ideology among many others.
} 
Ideas and conceptions of landscape resonate with notions of belonging and home, highlighting the intricate links between practices of place-making and "place-belongingness," i.e. a "personal, intimate, private sentiment of place attachment," of being at home in place (Antonsich 2010, 645). Belonging is most commonly related to a commonsense understanding as a "sense of belonging," which refers to a "feeling of being in place" (Mee \& Wright 2009, 772). Barbara Bender argues that we create a sense of self and belonging by "moving along familiar paths, winding memories and stories around places" $(2001,83)$. Thus, belonging can be considered a practical activity which "connects matter to place, through various practices of boundary making and inhabitation which signal that a particular collection of objects, animals, plants, germs, people, practices, performances, or ideas is meant 'to be' in a place" or not. Belonging, thus, carries an affective dimension as "people 'long' to achieve these types of connections, and to ensure that the ensemble of objects, human and nonhuman animals, practices, and ideas that accords with their version of belonging is achieved or maintained" (Mee \& Wright 2009, 772).

Belonging, as it implies non-belonging, is inherently political. Thus, landscapes are also imbricated in conflictual "politics of belonging" when socio-spatial in/exclusions are demarcated, negotiated and contested (Antonsich 2010, 644). Identities and positionings are constituted, mediated and articulated through landscapes (Schein 2009). Trudeau argues that landscapes are constructed through a territorialized politics of belonging, i.e. the symbolic and material practices, which maintain and correspond to the imagined geographies of the spaces that embody a polity $(2006,422)$. Landscapes are the means and products of spatial strategies to codify membership to a polity and its territory. The symbolic and material shape of a landscape emerges "in the interstices between the social processes in which ideas of region and landscape are created and $[\ldots]$ in the practices [that] make a place habitable through dwelling while creating the sense of community" necessary to sustain that place through time (Jones \& Olwig 2008, x). In what follows, I will draw on the interlinked notions of landscape and (be)longing as an analytical framework. How the Driesch landscape is a means and product of local residents' spatial strategies to achieve and sustain a sense of place-belongingness individually as well as a body politic will be analyzed. At the same time, residents engage in symbolic-material practices of boundary making, purifying the Driesch from what presumably does not belong.

\section{Making landscapes of (be)longing}

\subsection{Negotiating the polity of landscapes of (be)longing}

This dimension captures the ways in which a local community constitutes itself as a body politic through articulating claims to stewardship of a common resource, which forms part of their belonging. The land reforms of the 1970s and 1980s described above gradually abolished the customary law regulating the management regime of the Driesch pastures. The territorial restructuring (Kommunale Gebietsreform) circumscribed the self-governing rights of formerly autonomous village municipalities heavily (Henkel 2012, 312-316). The lost political autonomy following territorial reform marks a symbolic point of reference of the villagers' shared experience. The collective rights of use for grazing (Schweidgangsrecht) were transferred to the municipality as the legal successor of the village municipality (Ortsbürgermeisterei), which from then on, granted it to individual farmers for a small fee. Today, instead of customary law, an extensive legal framework of environmental regulations determine the management of Driesch areas (e.g. EU Habitats Directive, European Water Framework Directive, Federal Forest Act, state forest law, district landscape plan). Furthermore, the municipality, as the new landowner, converted the Driesch pastures into compensation areas, so-called eco-accounts, as a compensation for landscape interventions elsewhere (e.g. construction projects). The result was that existing tenures of the municipality with cattle farmers were phased out because reforestation with alluvial forest would yield more ecopoints (which are sold by the municipality to project developers) than grassland, as it was detailed by the employee of the nature conservation agency responsible for contractual agriculture (Interview 2018a).

The material face of the Driesch no longer represents the social face of the village polity because of the transformed political landscape. There is a widespread feeling of dispossession and foreign rule among the villagers. A member of the initiative, a woman in her late sixties, expresses 
resignation when she details the effects of territorial restructuring in the 1970s on the practices of house number poplar inheritance. Having grown up in the village and descending from an agricultural family lineage, the agronomist's biography is deeply intertwined with the customary Driesch management.

I wanted to go back to the poplars. These poplars are, of course, deeply rooted in the hearts of the people of [our village]. The land was communal land, it belonged to the community and the trees that stood on the Driesch belonged to the citizens and that was a kind of savings bank. When a young couple got married, these trees were cut down [...] the wood was sold and then the wedding and the trousseau and everything was paid for and the young couple subsequently replanted for their children. So, of course, there was intergenerational continuity, nowadays often referred to as sustainability. Then came the municipal restructuring, many citizens, unnerved, gave their poplars to the city [because of the tree tax]. (Interview 2018c)

The members of the initiative feel that the local "system has been broken" by the prohibition to replant poplar trees on their own. Consequently, they are trying to save their remaining trees against the odds of time, because a poplar tree is fit for cutting after 30-40 years and has to be removed before it is susceptible to red rot. Asked about the value of the remaining house number poplars, residents refer to the idealist value that these trees have as a memory of past experiences. Initiative members repeatedly refer in the interviews to childhood memories of cyclical visits to the Driesch with grandparents on Sundays, which formed part of the routine of "checking the trees." This common practice ensured that envious neighbors would not have drawn over house number marks on the trees. One of the spokespersons of the initiative, a long-term resident of the village in his fifties, makes plain that clinging to the trees is also a political claim for self-determination against the paternalism of the municipality:

It is, therefore, a sentimental approach to simply say: These are our trees, they bear the house number [...], this is the old Napoleonic house number and this is a piece of childhood memory of the father, of the grandfather who planted the trees. [...] And, to a certain extent, also defiance; one is always urged by the city to sell the trees, because the city always has only trouble with the tree owners, because they have to levy the tax, the tree tax, then the trees have to be felled by the city because some measures are planned. Then it's always, "Yes, sell us the trees." And there are a few people in the village who say, "No, we'll keep them." And, uh, they have to deal with us. (Interview 2019)

The spokesperson makes a strong plea for the retention of the remaining poplar trees, even though the customary rights and practices regulating their use have been severed. This claim extends beyond the individual to encompass the wider imagined community of the village polity, which was shaped by the practices of poplar forestry, use and inheritance. Acting through landscapes of (be)longing in this dimension entails the political claim that "a person or given group exists, that they have an identity and that they matter, thus claiming status and access to resources from others" (Waterton 2018, 97). At the same time, the very same spokesperson explains that he considers them (the villagers) as the "last Gallic village," thereby, alluding to the cultural (and military!) resistance of a notorious unnamed Gallic village against the hegemony of superior rule. Therefore, "we would like to keep the trees even if we no longer make a profit out of them. They form part of the cultural memory of the village, also of the past landscape - almost lost landscape." In this sense, the landscape of the Driesch is a political landscape fought over in a battle for political authority. Local residents draw on former customary laws and practices such as the poplar tree inheritance - in order to bolster their claim to stewardship of the Driesch. The Driesch is the scenery and part of the social acts through which the citizen initiative recognizes itself as a political community, defending their interpretation and rights to use of the landscape against planning decisions from 'outside.' 


\subsection{Living landscapes of (be)longing}

The notion of landscape as a deeply subjective and affective relation to a familiar environment is closely connected to the sense of landscape as "the place of dwelling and doing in the body politic of a community" (Olwig 2008, 81). The distinctively emotive character of this landscape is constituted by narratives, memories and repertoires of lived practice when "individual agents calling the landscape into being [...] make it relevant for their own lives, strategies and projects" (Rose 2002, 457). It is an emotionally saturated space which resonates with memories of place and engenders "place-belongingness" (Antonsich 2010, 644).

Such an emotional "place-belongingness" is, among others, performatively enacted and practiced in the embodied engagement with the material landscape (such as in practices of care and nurturing) creating an emotional involvement deeply imbued with the sensory experiences made in repeated encounters.

Many of the residents interviewed detailed their (childhood) memories of bodily engagements with the Driesch landscape at length. A member of the initiative and chairman of the local fishing association, a man in his fifties who has grown up in a neighboring village, asked about his personal relationship to the Driesch explained how he regularly went to a special place at the riverside and where he has spent "so many hours in his young years":

I grew up with cows. Cows are terribly curious animals and when you stand at the water and have a bag and a bucket and then you have to somehow- That's what you hear then [makes puffing noises], they snort like that and they have to go everywhere with their wet snouts and then, yes, you stroke them, you pat them a little on the neck and push them away. As I said, I've grown up with it. I'm not afraid to tackle them, but somehow - they are incredibly pushy. If you hear them, no, then better look, otherwise they push like that, then you're lying in water (laughs) if you're standing completely on the edge. Yes, well, I say, someday - of course you were also happy when there were no cows, then you could do everything like that, the bag and the bucket and then you had peace. But at some point, everything was overgrown [with weeds] and then you said: "Man, were there any cows left?"

The long-term resident expresses how his "place-belongingness" is mediated by bodily entanglements and affects in relationship to the living environment of his childhood memories, however, it is impaired by the inaccessibility of this place by the spread of giant hogweed. He knows the landscape emotionally through repeated visits to a familiar spot close to the riverside. His place-belongingness as an affective connection to the place (and the cows!) is embedded in bodily practices at the interface of a mindful body and the environment. In what follows, I want to expand upon the idea that "place-belongingness" is performed as an embodied involvement with the Driesch landscape, purposefully enacting specific emotions. Consequently, I will present an ethnographic vignette taken during the late summer of 2018 when I accompanied a resident on her everyday activity of walking the Driesch. The resident, a woman in her forties, moved to the village twenty years ago. She was involved in a prior initiative of sheep grazing on the Driesch pastures, which did not succeed due to the conservation regulations imposed by the lower nature conservation agency. These days, she visits the Driesch twice a day to walk her dogs.

We start the walk from the resident's house and, after a few meters, we reach a small path through which her dog has already run forward onto the Driesch. As we walk along, she expresses in great detail her knowledge of various landscape features. The Driesch cultivation was abandoned long before the storm that knocked over many poplar trees, she relates. We go to the dam, which used to be the main trail and is now completely overgrown, pass old fences, of which only the stumps protrude. One of the members of the initiative temporarily keeps the path clear, she says, but she perceives the current appearance of the pasture as decay. "And yes, I say, after the storm, it changed very negatively, in my eyes, through this nature reserve, where nothing can be changed. Everything just stayed as it was. It resembles a desert landscape. Everywhere these giant craters and the dead trees that just lie everywhere and everything is overgrown." The esthetics and usability intertwine intimately for her: "Yes, I say, if you look at something 
beautiful, well-kept, which is, nevertheless, natural, it is more beautiful than if you now look at this wildly overgrown." Repeatedly, we pass fence slats with barbed wire that have fallen over and rotted. The giant root plates of fallen trees make her sad, "Especially in the winter when things are no longer green and you can only see the huge craters and mountains of roots," she proclaims. The noise of the wind rustling in the poplar treetops, on the other hand, gives her the easing impression of an ocean shore.

In this account, the resident verbalizes her subjective experience of the Driesch landscape in which sensory experiences, sense-making and affects intertwine. Her experience of the Driesch landscape is based on a sensorium that has developed in the practical everyday use of the landscape, which is "known by those who dwell within it, by the skills of involved practice" (Cloke 2013, 233). Her body articulates a taskscape in the embodied practice of walking in the form of traces and, conversely, the taskscape has inscribed itself into her body as living memories. The overgrown paths of an estranged and, at times, uncanny landscape disrupt her place-belongingness. However, she responds emotionally to the familiar characteristics of the Driesch, the remaining poplar trees, which prompt affective memories as part of her enactment of belonging. In this sense, her place-belongingness is more than human and relational; it is performed in the everyday activities of walking and sensing the landscape which involve affective (positive and negative) encounters with the poplar trees and other landscape elements co-creating her belonging. As such, it is not predetermined but enacted in responsive ways through her doing and knowing the landscape. As much as the poplar trees form part of the residents' "place-belongingness," it is also clear what does not: The "invasive alien species" overgrowing the familiar landscape, i.e., giant hogweed and glandular balsam. Belonging, in the sense of a shared feeling of familiarity and connection to what it is like, implies non-belonging of what is unlike and excluded. Forms of non-belonging are achieved in symbolic-material practices of boundary making in spatial arenas, and the following section sheds light on the politics of in/exclusion in the making of landscapes of (be)longing.

\subsection{Landscapes as arenas of belonging}

In what follows, I want to investigate how landscapes of (be)longing are spatial arenas through which who and what belongs 'in place' or not is imagined, negotiated and codified and how such belonging is achieved. In these ways, landscapes are imbricated in territorialized "politics of belonging" to react against transformative pressures from 'outside': "landscapes represent sociospatial practices aimed at fixing boundaries, imposing cultural coherence and stabilizing meaning as a response to the 'inherent unboundedness' and instability of the social world" (Trudeau 2006, 437). The residents interviewed experience the Driesch, overgrown with giant hogweed and glandular balsam, as a landscape under threat which has to be defended. Their narratives are structured by metaphors of loss and alienation, disorder and reconquest of the "neophyte jungle." The "invasive neophytes" who do not regard the symbolic ordering of space are the agents of transformation in the residents' narratives, even though the altered material landscape is the result of the residents' transformed taskscapes. The "invasive neophytes" displace the familiar, overgrow the "natural landscape, a landscape that fits to this region and which has also shaped the people over centuries" (Interview 2018c). The spokesperson of the initiative when asked about what he considers problematic about the spread of these species, explains:

Yeah, what's wrong with neophytes? What I actually find bad about them is that they overgrow and displace all the customary vegetation. If you look at the Driesch, all the other plants that used to live there no longer have any space, they simply become overgrown and you really have a monoculture of balsam and Hercules [giant hogweed]. (Interview 2018c)

Residents' gradually loose the perception of the Driesch landscape's distinctive characteristics dissolving into wilderness. They feel left alone by local authorities in view of the perceived threat posed by glandular balsam and giant hogweed. Even more so, they feel excluded from taking measures themselves by the existing nature conservation regulation: "The whole idea of nature, which is left to itself in a cultural landscape, is actually a re-wilding of a cultural landscape. Many 
people have understood that and somehow they want to see it more orderly again" (Interview 2018c).

It is, first and foremost, the EU Habitats Directive based on the paradigm of process protection (Prozessschutz), which places restrictions on the use of the Driesch. The rationality of the Habitats Directive is to establish a coherent ecological "Natura 2000 network" at the heart of the European conservation policy. Based on bioscientific expert knowledge, it aims to safeguard the undisturbed "natural development" of generally typified habitats and species (i.e. alluvial forest and related species in the Driesch area) which are defined as worthy of conservation. The Natura 2000 database entry for the area does not refer to contemporary forms of human habitation or the historical social-ecology that has developed in the place. Instead of the cultural landscape, the development of wilderness is considered the highest protection goal. It is no longer 'man' who shapes the landscape through his uses, but all meaningful development potential is projected into nature: It should, finally, be able to come to itself, so that the protection of wilderness processes becomes central because it is constantly changing.

The local authorities responsible for the management and implementation of planning and conservation regulations (district forest authority, lower nature conservation agency, local authority estate office) point unanimously to the overarching regulatory framework in order to legitimize the non-intervention in the area, thereby, relegating analysis and expertise to higher scales of governance. However, at the same time, they problematize the spread of "invasive neophytes" because it runs counter to the conservation objectives and development goals as formulated in the Habitats Directive (natural forest development). However, as seeds of the invasive alien species move along the river downstream, local authorities consider their spread as a transgression from 'outside' their sphere of action, where the problem is to get down to the root of the trouble (Interview 2018d; Interview 2018b; Interview 2018e).

This strategic upscaling and horizontal shifting of responsibility had led residents to take measures on by themselves. They engage in symbolic-material practices of othering and purification, classifying giant hogweed and glandular balsam as 'out of place,' and they have to be fought with draconian measures. The seedlings of the giant hogweed are removed in spring in some places by members of the initiative in a collective action. Since the manual combating of the "invasive neophytes" is not very promising in the long run, it is especially the collective sensemaking of the ritual practice in which a "community of fate" experiences itself through the joint work on the Driesch (Everts 2015, 205). The transgression of "invasive species" forms a context in which the initiative reconstructs the order of the Driesch, asserts its sense of place (i.e. the prescriptions, values and esthetic judgments of the initiative) and experiences itself as a body politic. Moreover, in these symbolic-material practices, they assert their claim to stewardship of this landscape vis-à-vis local authorities, who are displayed as 'outsiders' incapable of managing the area properly. In this sense, "politics of belonging" are fruitful entry points to make visible arenas of a conflictual "more-than-human world-making" through which political claims over landscape stewardship are articulated and negotiated (Tsing 2017,3).

\subsection{Landscapes of longing}

While the prior dimensions concentrated on the symbolic-material and embodied practices of perceiving, interpreting and making landscapes of belonging, this dimension is about their idealistic freight in cultural imagery. Longing encapsulates the idea that landscapes conserve the nostalgic-utopian image of ideal harmonious human-nature relations in their material and symbolic fabric (Massey 2006, 39). This timely dimension of landscapes of (be)longing links the present to the future through an imagined past. It is simultaneously backdrop and horizon, as past images of the landscape are evoked in order to envision the future. The LEADER initiative practically constructs, evokes and performatively enacts a spatial image of the Driesch as an Arcadian topos of work and leisure in close connection with peaceful nature in the course of their activities, for example, through history days and publications (Müller 2021). Spatial images refer to collectively shared symbolic orders and can be 'deciphered' by many people; they support individual and collective worldviews, sense-making and identity formation (Ipsen 2006). In this way, they form an integral part of "place-belongingness" (Antonsich 2010). Emblematically, 
the spokesperson of the initiative articulates this spatial image against the backdrop of his own childhood memories:

As a child, I was with the herdsman on the Driesch. We walked in nature, high poplar trees [...] lush green meadows, lots of flowers, watercourses to jump through. [...] Just to see the life in nature, with nature, with agriculture, the cycle, [...] the driving of the animals on the Driesch; in the evening, they all came back again. An agriculture that we are longing for today. And [...] I think that this is all part of it, it's all part of the landscape of the Driesch. So, when you go to the Driesch [...] you have nature, you see all kinds of wild animals, but also the cattle. It was simply a symbiosis of human use and natural landscape. (Interview 2018c)

The spokesperson evokes a spatial image the Driesch as the material manifestation and symbol of the longing for harmony between man and nature. It fluctuates between a nostalgic longing for a paradise lost and a utopian imaginary of restored harmony, envisioned as agro-ecological relationships (Berr \& Kühne 2020, 21).

Tim Ingold $(2018,160)$ finds such longing to oscillate between "an imagination that lies beyond the horizon of conceptualization [and] loops proleptically back to meet an origination that lies beyond the reach of memory." It is "a place where past and future merge. It is a place we perceptually dream of and strive for, but never reach." The agronomist of the initiative describes this non-simultaneity and tension between a present longing for an (imaginary) place in the future in the focus group interview:

\begin{abstract}
And this way of living with and through and in nature has been systematically disconnected for 30 years. And today people are completely disconnected from [...] living through nature. Where do I get my food from? From nature. [...] and that has been decoupled. I'm talking about food from nature now and not food from pure, industrialized agriculture. This is no longer nature, it's a stable somewhere in the middle of nowhere. But these are the things that people sometimes yearn for without knowing it. So somehow intuitively people say: "Yes, that would be nice," and then they are drawn to areas like here and to other areas where there are remnants or beginnings. (Interview 2018c)
\end{abstract}

However, instead of indulging in escapism, residents mobilize their longing towards a critical reflection of the present condition of agricultural production in order to envision an unrealized potential in the future. Thus, their spatial image of the Driesch provides a sense of orientation in the light of current socio-ecological landscape transformations. For the members of the initiative, the spatial image of Driesch serves as moral-esthetic contrast to the surrounding landscape shaped by industrialized agriculture. These rationalized and monofunctional landscapes are despised as the symbol of a severed human-nature relationship. Even though the spatial imagery of the Driesch enacted by the LEADER initiative is discarded by institutional actors of landscape governance as nostalgic and based on (esthetic) sentiments, it provides residents with a vision to develop their region.

\title{
7. Discussion and Concluding Remarks
}

The preceding arguments have illustrated how local residents articulate four interrelated senses of (be)longing in the material-semiotic reshaping of the Driesch and how they strategically make use of the LEADER initiative in order to impose their perceptions, interpretations and moralesthetic judgments in a battle over political authority to intervene in the cultural landscape. For the citizen initiative, it is not the dilemma to participate either in formal planning procedures or to resist but joining formal participatory arrangements in rural governance enhances their capacities to resist institutional discourses on other scales of governance, technical expertise and regulatory management. Furthermore, how the citizen initiative becomes engaged as a new knowledge actor 
in the multi-level and multi-actor policy framework of landscape governance could be pointed out. Local residents pit their locally situated counter-knowledge of the Driesch as the materialization of their biocultural heritage against the authorized technical expertise of "outsiders," i.e. the lower nature conservation agency and the forest authority, as competing knowledge actors. Even though some experts dismiss the initiative's knowledge claims as sentimental and based on nostalgic longings, the initiative mobilized support for their LEADER project among local conservative political elites and federal members of parliament of the Green party. In this way, they manifest their culturally based logics of conservation as matters of concern.

In contrast to matters of fact, matters of concern are inclusive of and saturated by "moral considerations, esthetic judgements, political controversies and cultural concerns" (Welz 2015, 128). By becoming part of the village's biocultural heritage, the Driesch is transformed into a "highly complex, historically situated, richly diverse" matter of concern by the LEADER initiative (Latour 2004, 237). This enables residents to contest bioscientific expert knowledge and create ontological disturbances as to what the Driesch is and what its future development should entail. Remarkably, the environmental knowledge controversy unleashed by the LEADER initiative did not ultimately turn on the question of producing more factual or accurate knowledge of the Driesch but rendered a substantive epistemological divide between divergent knowledge regimes visible. While the initiative, forming a "knowledge polity" (Whatmore 2009), bases its knowledge construction on highly particular everyday perceptions, experiences and practices of doing a living cultural landscape, the landscape governance experts considered the Driesch as a segmented scientific object, easily decomposable into its elements - the species, habitats and their relationships and the abiotic features of the landscape. Eventually, differences did not only concern the knowledge strategies pursued (knowing the landscape through sensory encounters, embodiment and in memory as opposed to cartographic practices of biotope mapping) but the object of knowledge itself. Mapping the divergent epistemologies of scientific environmentalism and the cultural logics of biocultural heritage points to the epistemic disjuncture, erasures and exclusions on the contested terrain of environmental governance. Participatory landscape management makes localized holistic models of human-environmental relationships visible and offers the potential to redistribute expertise to those concerned.

Limited in terms of generalizability due to its confined empirical base of one LEADER initiative in a particular focus region, this article, nevertheless, points to future issues of research. These observations have implications for the reconstruction of cultural landscapes in the context of multilevel rural development and multilayered landscape management. In order to grasp the dynamics of rural landscape transformations at the interface between policy regimes (re-territorializing and de-territorializing) and everyday practices of landscaping, rural landscape studies need to engage with and strengthen the understanding of everyday perceptions, interpretations and practices of landscaping as opposed to sectoral fragmentation of landscapes in policy departments and segmented disciplinary views. In this way, cultural and social sciences can "add reality to scientific objects" (Latour 2004, 237) and arrive at a more nuanced understanding of how landscapes become imbricated, are transformed by and are the arena for matters of concern such as constructing a sense of belonging in rapidly transforming environments. Conversely, this also means to think "how they in turn force us to think and feel - through their contexts, prompts and familiarity (or not)" (Waterton 2018, 95). This means moving beyond the pertinent paradigm to approach landscapes, first and foremost, as a pictorial way of representation, a cultural image, to focus on the manifold ways meaningful environmental relationships are enacted in embodied and relational entanglements. Landscapes from this perspective are animated spaces, "in terms of the entwined materiality and sensibilities with which we act and sense" (Wylie 2005, 245), while, at the same time, they are co-productive agents in the formation of shared experiences, identities and the articulation of political positions. Eventually, such an endeavor should strengthen our understanding of the liveliness, power and relationality of more-than-human socialites in negotiating rural landscape change. 


\section{Acknowledgement}

I am grateful to the two anonymous reviewers for their careful reading of the manuscript and the productive comments and suggestions for its improvement. Some of the data, including (place) names and personal information has been anonymised by the author to maintain full anonymity. This information was not integral to the analysis.

\section{Academic references}

[1] Abrams, Jesse B., Gosnell, H., Gill, N. J. \& Klepeis, P. J. (2012). Re-creating the rural, reconstructing nature. An international literature review of the environmental implications of amenity migration. Conservation and Society 10(3), 270-284. DOI: 10.4103/09724923.101837.

[2] Ahmed, S. (2004). Collective feelings: or, the impressions left by others. Theory Culture \& Society 21(2), 25-42. DOI: 10.1177/0263276404042133.

[3] Almstedt, A., Brouder, P., Karlsson, S. \& Lundmark, L. (2014). Beyond post-productivism: from rural policy discourse to rural diversity. European Countryside 6(4), 297-306. DOI: 10.2478/euco-2014-0016.

[4] Antonsich, M., (2010). Searching for belonging: an analytical framework. Geography Compass 4(6), 644-659. DOI: 10.1111/j.1749-8198.2009.00317.x.

[5] Bender, B. (2001). Landscapes on-the-move. Journal of Social Archaeology 1(1), 75-89. DOI: $10.1177 \% 2 F 146960530100100106$.

[6] Bieling, C., Plieninger, T. \& Trommler, K. (2011). Cross the border - close the gap: resiliencebased analysis of landscape change. European Countryside 3(2), 83-92. DOI: 10.2478/v10091-011-0005-0.

[7] Berr, K. \& Kühne, O. (2020). Und Das Ungeheure Bild Der Landschaft... The genesis of landscape understanding in the German-speaking regions. Wiesbaden: Springer.

[8] Bohnsack, R., Meuser, M. \& Geimer, A., eds. (2018). Hauptbegriffe Qualitativer Sozialforschung. München: UTB.

[9] Bridgewater, P., Rotherham, ID. (2019). A critical perspective on the concept of biocultural diversity and its emerging role in nature and heritage conservation. People and Nature 1, 291-304. DOI: 10.1002/pan3.10040.

[10] Bruns, D., Kühne, O., Schönwald, A. \& Theile, S. (2015). Landscape culture - culturing landscapes: the differentiated construction of landscapes. Wiesbaden: Springer.

[11] Cejudo, E., Toro, F. \& Castillo, J. (2020). Agrarian heritage as an example of the sustainable and dynamic use of natural resources. LEADER projects in Andalusia 2007-2013. In Cejudo E. \& Navarro, F., eds., Neodendogenous development in European rural areas. Results and lessons (pp. 251-282). Basel: Springer.

[12] Clarke, R. (2015). Beyond landscape designation: innovative funding, delivery and governance and the UK protected area system. Management of Environmental Quality: An International Journal 26(2), 172-194. DOI: 10.1108/MEQ-07-2014-0106.

[13] Cloke, P. (2013). Rural landscapes. In Johnson, N. C., Schein, R. H. \& Winders, J., eds., The Wiley-Blackwell companion to cultural geography, Volume 11 (pp. 225-237). Chichester UK: John Wiley \& Sons, Ltd.

[14] Eriksson, O. (2018). What is biological cultural heritage and why should we care about it? An example from Swedish rural landscapes and forests. Nature Conservation 28, 1-32. DOI: 10.3897/natureconservation.28.25067. 
[15] Everts, J. (2015). Invasive life, communities of practice, and communities of fate. Geografiska Annaler: Series B, Human Geography 97(2), 195-208. DOI: $10.1111 /$ geob.12074.

[16] Furmankiewicz, M., Thompson, N., Zielińska, M. (2010). Area-based partnership in rural Poland: the post-accession experience. Journal of Rural Studies 2, 52-62. DOI: 10.1016/j.jrurstud.2009.05.001.

[17] Gavin, M. C., McCarter, J., Mead, A., Berkes, F., Stepp, J. R., Peterson, D. \& Tang, R. (2015). Defining biocultural approaches to conservation. Trends in Ecology \& Evolution 30(3), 140145. DOI: 10.1016/j.tree.2014.12.005.

[18] Gelencsér, G., Vona, M. \& Centeri, C. (2012). Loosing agricultural heritage in rural landscape - a case study in Koppány Valley Area, Hungary. European Countryside 4(2), 134-146. DOI: 10.2478/v10091-012-0019-2.

[19] Halfacree, K. (2006). Rural space: constructing a three-fold Architecture. In Cloke, P., Marsden, T. \& Mooney, P., eds., The handbook of rural studies (pp. 44-62). London: SAGE Publications.

[20] Heatherington, T. (2012). Remodeling the fortress of conservation? Living landscapes and the new technologies of environmental governance. Anthropological Forum 22(2), 165-185. DOI: $10.1080 / 00664677.2012 .694172$.

[21] Heidner, S. (2018). Recultivation of Drieschlandschaft at Barmen through extensive agricultural use. Ecological, socioeconomic and landscape conservation effects on natural and cultural regions. Aachen: RWTH.

[22] Henkel, G. (2012). Das Dorf. Landleben in Deutschland-gestern und heute. Darmstadt: WBG (Wiss. Buchges.).

[23] Ingold, T. (2000). The perception of the environment. London \& New York: Routledge.

[24] Ingold, T. (2018). One world anthropology. HAU- Journal of Ethnographic Theory 8(1-2), 158-171. DOI: 10.1086/698315.

[25] Ipsen, D. (2006). Ort und Landschaft. Wiesbaden: VS Verlag.

[26] Jansson, M., Vogel, N., Fors, H. \& Randrup, T. B. (2019). The governance of landscape management: new approaches to urban open space development. Landscape Research 44(8), 952-965. DOI: 10.1080/01426397.2018.1536199.

[27] Jones, M. \& Olwig, K. R. (2008). Nordic landscapes. Region and belonging on the northern edge of Europe. Minneapolis: University of Minnesota Press.

[28] Kidd, S. (2013). Landscape planning: reflections on the past, directions for the future. In Howard, P., Thompson, I., Waterton, E. \& Atha, M., eds., The Routledge companion to landscape studies (pp. 384-400). London \& New York: Routledge.

[29] Kusters, K., Buck, L., de Graaf, M., Minang, P., van Oosten, C. \& Zagt, R. (2018). Participatory planning, monitoring and evaluation of multi-stakeholder platforms in integrated landscape initiatives. Environmental Management 62(1), 170-181. DOI: 10.1007/s00267017-0847-y.

[30] Kamvasinou, K. \& Stringer, B. (2019). The politics of rurality. Landscape Research 44(7), 783-786. DOI: 10.1080/01426397.2019.1641260.

[31] Konečný, O., Binek, J., Svobodová, H. (2020). The Rise and Limits of Local Governance: LEADER/Community-Led Local Development in the Czech Republic. In: Nunes Silva C., ed., Contemporary Trends in Local Governance. Local and Urban Governance (pp. 173-193). Cham: Springer. DOI: 10.1007/978-3-030-52516-3_9.

[32] Kulmer, A. (2012). Historical assets and related landscape. Towards a new cultural heritage policy for rural areas in Europe. Zoll+ 21, 92-95.

[33] Kühne, O. (2019). Landscape theories: a brief introduction. Wiesbaden: Springer. 
[34] Latour, B. (2004). Why has critique run out of steam? From matters of fact to matters of concern. Critical inquiry, 30(2), 225-248. DOI: 10.1086/421123.

[35] Lindholm, K.-J. \& Ekblom, A. (2019). A framework for exploring and managing biocultural heritage. Anthropocene 25, 100195-100205. DOI: 10.1016/j.ancene.2019.100195.

[36] Lowe, P., Phillipson, J., Proctor, A. \& Gkartzios, M. (2019). Expertise in rural development: a conceptual and empirical analysis. World Development 116, 28-37. DOI: 10.1016/j.worlddev.2018.12.005.

[37] Marango, S., Bosworth, G. \& Curry, N. (2020). Applying neo-endogenous development theory to delivering sustainable local nature conservation. Sociologia Ruralis. DOI: $10.1111 /$ soru.12315.

[38] Massey, D. (2006). Landscape as a provocation: reflections on moving mountains. Journal of Material Culture 11(1-2), 33-48. DOI: 10.1177/1359183506062991.

[39] Mee, K. \& Wright, S. (2009). Geographies of belonging. Why belonging? Why geography? Environment and Planning A-Economy and Space 41(4), 772-779. DOI: 10.1068/a41364.

[40] Müller, O. (2021). Der Driesch - Die (Re)Konstruktion einer historischen Kulturlandschaft. Territoralisierungspraktiken im Kontext des LEADER-Prgogramms. In: Fenske, M., Peselmann, A. \& Best, D., eds., Ländliches vielfach! Leben und Wirtschaften in erweiterten sozialen Entitäten. Bielfeld: Transcript.

[41] Müller, O., Sutter, O. \& Wohlgemuth, S. (2020). Learning to LEADER. Ritualised performances of 'participation' in local arenas of participatory rural governance. Sociologia Ruralis 60(1), 222-242. DOI: 10.1111/soru.12287.

[42] Olwig, K. R. (2008). Performing on the landscape versus doing landscape: perambulatory practice, sight and the sense of belonging. In Ingold, T. \& Vergunst, J., eds., Ways of walking: ethnography and practice on foot (pp. 81-91). London: Routledge.

[43] Olwig, K. R. (2013). Globalism and the enclosure of the landscape commons. In Rotherham, I. D., ed., Cultural severance and the environment - The ending of traditional and customary practice on commons and landscapes managed in common (pp. 31-46). Dordrecht: Springer.

[44] Pollermann, K., Raue, P. and G. Schnaut (2014). Opportunities for a participative approach in rural development: findings from LEADER in Mecklenburg-Vorpommern and the requirements for community led local development. Landbauforsch 64(3/4), 127-138.

[45] Pollermann, K., Aubert, F., Berriet-Solliec, M., Laidin, C., Lépicier, D., Pham, H., Raue, P. \& Schnaut, G. (2020). Leader as a European Policy for Rural Development in a Multilevel Governance Framework: A Comparison of the Implementation in France, Germany and Italy. European Countryside 12(2), 156-178. DOI: 10.2478/euco-2020-0009.

[46] Printsmann, A., Kruse, A. \& Roth, M. (2012). Introduction for living in agricultural landscapes: practice, heritage and identity. European Countryside 4(2), 89-100. DOI: 10.2478/v10091012-0016-5.

[47] Probyn, E. (1996). Outside belongings. London: Routledge.

[48] Ray, C. (2001). Culture economies: a perspective on local rural development in Europe. Newcastle upon Tyne: Centre for Rural Economy.

[49] Rose, M. (2002). Landscape and labyrinths. Geoforum 33(4), 455-467. DOI: 10.1016/s00167185(02)00030-1.

[50] Rotherham, I. D. (2015). Bio-cultural heritage and biodiversity: emerging paradigms in conservation and planning. Biodiversity and Conservation 24, 3405-3429. DOI: $10.1007 / \mathrm{s} 10531-015-1006-5$.

[51] Schein, R. H. (2009). Belonging through land/scape. Environment and Planning A, 41(4), 811-826. DOI: 10.1068/a41125. 
[52] Selman, P. (2006). Planning at the landscape scale. London: Routledge.

[53] Stemmer, B., Philipper, S., Moczek, N. \& Röttger, J. (2019). Die Sicht von Landschaftsexperten und Laien auf ausgewählte Kulturlandschaften in DeutschlandEntwicklung eines Antizipativ-Iterativen Geo-Indikatoren-Landschaftspräferenzmodells (AIGILaP). In Berr, K. \& Jenal, C., eds., Landschaftskonflikte (pp. 507-534). Wiesbaden: Springer.

[54] Taylor, K., Clair, A. S. \& Mitchell, N. J. (2014). Conserving cultural landscapes: challenges and new directions (Vol. 7). New York \& London: Routledge.

[55] Trudeau, D. (2006). Politics of belonging in the construction of landscapes: place-making, boundary-drawing and exclusion. Cultural Geographies 13(3), 421-443. DOI: $10.1191 / 1474474006$ eu366oa.

[56] Tsing, A. (2017). The buck, the bull, and the dream of the stag: some unexpected weeds of the Anthropocene. Suomen Antropologi: Journal of the Finnish Anthropological Society 42(1), 3-21.

[57] Waterton, E. (2018). More-than-representational landscapes. In Howard, P., Thompson, I., Waterton, E. \& Atha, M., eds., The Routledge companion to landscape studies (pp. 91-101). London: Routledge.

[58] Welz, G. (2015). European products: making and unmaking heritage in Cyprus. Oxford: Berghahn.

[59] Whatmore, S. J. (2009). Mapping knowledge controversies: science, democracy and the redistribution of expertise. Progress in Human Geography, 33(5), 587-598. DOI: $10.1177 / 0309132509339841$.

[60] Woods, M. (2007). Engaging the global countryside: globalization, hybridity and the reconstitution of rural place. Progress in Human geography 31(4), 485-507. DOI: $10.1177 / 0309132507079503$.

[61] Wright, S. (2020). 'Belonging'. In Kobayashi, A. ed., International encyclopedia of human geography (pp. 294-299). Amsterdam: Elsevier.

[62] Wylie, J. (2005). A single day's walking: narrating self and landscape on the South West Coast Path. Transactions of the Institute of British Geographers, 30(2), 234-247.

[63] Yuval Davis, N. (2011). The politics of belonging: intersectional contestations. London: SAGE.

Other sources

[64] CoE: Council of Europe (2000). European Landscape Convention. European Treaty Series 176. Strasbourg: Council of Europe. Last accessed on 23.07.2020, https://www.coe.int/en/web/conventions/full-list/-/conventions/treaty/176.

[65] HFR: Höhere Forstbehörde Rheinland (1986). Waldflächenentwicklung im Rheinland 1820 1980. Bonn: HFR.

[66] LANUV: Landesamt für Natur, Umwelt und Verbraucherschutz Nordrhein-Westfalen (2013). DE-5003-301 Kellenberg und Rur zwischen Flossdorf und Broich. Last accessed on 23.07.2020, http://natura2000-meldedok.naturschutzinformationen.nrw.de/natura2000meldedok/web/babel/media/zdok/DE-5003-301.pdf.

[67] Local Development Strategy (LDS): Schichtwechsel. Regionale Entwicklungsstratgie: LEADER-Bewerbung für die Förderperiode 2014-2020, last accessed on 23.03.17, https://www.inde-rur.de/wp-content/uploads/2020/06/200616-res-weboptimiert.pdf. 
[68] LWL \& LVR: Landschaftsverband Westfalen-Lippe \& Landschaftsverband Rheinland (2007). Kulturlandschaftlicher Fachbeitrag zur Landesplanung in Nordrhein-Westfalen. Last accessed on 23.07.2020, http://www.Iwl.org/302a-download/PDF/kulturlandschaft/Teil1 .pdf. 